\title{
MÁQUINAS E MENTES: interpretando a metáfora
}

\author{
MACHINES AND MINDS: \\ a metaphor interpretation
}

Ivelã Pereira

Graduanda em Letras Português - UFSC

Heronides Maurílio Melo Moura

Docente do Programa de Pós-Graduação em Lingüística - UFSC

\section{Resumo}

O artigo tem por objetivo testar a hipótese de Moura (2007) de que as metáforas possuem uma estrutura léxico-conceptual e de que há sistematicidade na interpretação metafórica, ou seja, há uma regularidade interpretativa conforme a classe verbal (ou nominal) dos veículos das metáforas. Para chegar ao objetivo, selecionamos alguns verbos de atitude proposicional e procuramos na web exemplos do uso desses verbos em relação a máquinas. Os verbos escolhidos como veículos das metáforas foram: pensar, raciocinar, surtar, pirar, enlouquecer, inventar, criar, decidir, saber, acreditar, entender, aceitar, querer, achar; e os tópicos selecionados: computador, celular, aparelho, televisão, microondas, avião, carro, piloto automático, termostato, aparelho e máquinas. A coleta resultou em 51 exemplos que constituem metáforas ontológicas de personificação e, por causa da relação estreita desse tipo de metáfora com a discussão sobre Inteligência Artificial, foi feita uma breve seção sobre esse assunto. A partir dos dados coletados, a análise foi efetuada objetivando parafrasear e buscar relações paradigmáticas e sintagmáticas relativas às metáforas selecionadas. Após a discussão dos resultados, a hipótese pôde ser confirmada e, através da análise, é possível mostrar que há regularidade na interpretação de metáforas cujos tópicos são máquinas e cujos veículos são verbos de atitude proposicional. Foi averiguado que, quando verbos de atitude proposicional são aplicados metaforicamente a máquinas, visa-se basicamente ao funcionamento dos equipamentos e à manipulação de símbolos pelas máquinas, mas não a atitudes conscientes ou estados da "mente" das máquinas, o que mostra a limitação da analogia metafórica entre máquinas e mentes.

Palavras-chave: Metáfora. Estrutura léxico-conceptual. Verbos de atitude proposicional. Inteligência Artificial.

\begin{abstract}
This paper aims to test Moura's (2007) hypothesis that metaphors have a lexiconconceptual structure and that there is a systematicity in metaphor interpretation, i. e., there is an interpretative regularity depending on the verbal (or noun) class of metaphor vehicles. For so some propositional attitude verbs were selected and uses of these verb examples related to machines were searched on the web. The verbs chosen as metaphor vehicles were: to think, to reason, to craze, to flee, to go crazy, to invent, to create, to decide, to know, to believe, to understand, to accept, to want, to find; and the selected topics: computer, cellular, device, television, microwave, airplane, car, automatic pilot, thermostat, device and machines. The search resulted in 51 samples of personification
\end{abstract}


ontological metaphors. Because of the narrow relation of this metaphor type with discussions on Artificial Intelligence a brief section on this subject was included. The collected data were analyzed in order to paraphrase and to search for paradigmatic and syntagmatic relations associated to the selected metaphors. After the discussion on results the hypothesis was confirmed. Through this analysis it was possible to show that there is regularity in the interpretation of metaphors which have machines as topics and propositional attitude verbs as vehicles. It was verified that when propositional attitude verbs are applied in a metaphorical sense to machines they basically refer to the machines work and to the symbol manipulation made by them and not to conscientious attitudes or machines "states of mind", which shows the limitation of metaphorical analogy between machines and minds.

Keywords: Metaphor. Lexicon-conceptual structure. Propositional attitude verbs. Artificial Intelligence.

\section{INTRODUÇÃO}

A metáfora é estudada até hoje nas escolas como uma simples figura de linguagem, usada apenas em contextos específicos, como na linguagem literária. A causa disso é a permanência da visão clássica da metáfora nas gramáticas e nos manuais didáticos, no entanto, graças aos estudos filosóficos e lingüísticos contemporâneos acerca da metáfora, esta não é mais vista como um ornamento utilizado em linguagens específicas. Ao contrário disso, alguns teóricos mais recentes consideram a metáfora como uma forma corriqueira de linguagem, empregada com freqüência no cotidiano das pessoas e até mesmo na linguagem científica. O livro de Lakoff e Johnson "Metaphors we live by" (1980) traz muitos exemplos de metáforas comuns no dia-a-dia dos indivíduos, como, por exemplo, as metáforas: "Ela lutou por ele, mas sua amante venceu." e "Ele é conhecido por suas inúmeras conquistas rápidas." (LAKOFF; JOHNSON, 2002, p. 115). Com base nessas metáforas e em outras semelhantes que aparecem no livro, os autores postulam um tipo de metáfora: AMOR É UMA GUERRA. Para cada grupo de exemplos, Lakoff e Johnson (1980) criam uma nova metáfora, que serve para descrever a natureza sistemática dos conceitos metafóricos. Os exemplos citados na obra são sempre relacionados ao cotidiano das pessoas, mostrando que a metáfora não está apenas na poesia, mas é utilizada com freqüência sem que percebamos. Apesar de não adotarmos a teoria desses autores e seguirmos a linha interacionista, criticada por Lakoff e Johnson (1980), assumimos a virada cognitivista postulada pelos autores.

Mas não é só na linguagem coloquial que as metáforas são utilizadas. A linguagem científica também se serve da metáfora para definir conceitos; a expressão "ondas sonoras” é um exemplo claro de que o uso metafórico é essencial para compor certas noções que a linguagem literal talvez não ilustre tão bem, por isso, para Ullmann (1964, p. 442), a metáfora funciona como “[...] um meio de preencher lacunas no vocabulário.”

Nesse artigo, adotamos a linha interacionista que, diferentemente da teoria estruturalista de Ullmann (1964), não vê a metáfora como uma mudança de significado apenas, isto é, uma superposição de uma acepção nova à acepção antiga da palavra, mas afirma que há uma interação entre o tópico e o veículo do enunciado metafórico, por isso, não há uma substituição de significados, porém um ponto de intersecção entre os significados do 
tópico e do veículo no enunciado metafórico. "Nessa tradição (interacionista), não se fala de palavras metafóricas, mas de enunciados metafóricos.” (MOURA, 2008, p. 8).

Max Black é um dos representantes da linha interacionista. Para Black (1993), as metáforas são criadas por interações entre dois sistemas, com base em analogias (em parte criadas, em parte descobertas). O autor mostra também como as metáforas trabalham e diferencia símiles de metáforas, propondo um método de reconhecimento da metáfora. Explica, ainda, que a metáfora cria conceitos que não podem ser parafraseados, portanto a metáfora seria um meio de linguagem único sem qualquer forma de substituição.

Em relação a esse aspecto, diferentemente de Black (1993), Searle (1993), que defende a teoria pragmática da metáfora, afirma que toda metáfora possui uma paráfrase literal. A posição adotada neste artigo, em relação a isso, é a seguinte: toda metáfora pode ser parafraseada parcialmente, mas jamais totalmente, pois a estrutura metafórica implica sempre uma inovação, uma mutação semântica e conceptual.

Ricoeur (1989) se aproxima de Black (1993) quando afirma que as metáforas são insights cognitivos, pois representam um novo conceito. Ricoeur (1989) nos apresenta uma teoria baseada no interacionismo da metáfora e critica a teoria da substituição e a teoria comparativa. Ele define metáfora como sendo um ponto de interseção entre campos semânticos. Depois de apresentar um panorama dos estudos estruturalistas e sua relação com a metáfora, o autor conclui que o lugar da metáfora na linguagem é entre as palavras e as frases, entretanto não nega a importância do pensamento na construção metafórica; afirma que “[...] se a metáfora é uma habilidade, um talento, é um talento de pensamento.” (RICOEUR, 1989, p. 125).

Alguns autores (por exemplo, Lakoff; Johnson, 1980) afirmam que a metáfora está apenas no pensamento, e outros (por exemplo, Ullmann, 1964), que ela está somente na linguagem. Por outro lado, situa-se a metáfora seja no âmbito da palavra, seja no âmbito da sentença. Moura (2008) critica as duas dicotomias que envolvem o estudo metafórico: pensamento e linguagem, e palavra e sentença. Por fim, conclui que, para a construção de um enunciado metafórico, o pensamento e a linguagem precisam estar juntos, ou seja, a metáfora está ancorada numa estrutura léxico-conceptual, de modo que o autor assume as propostas de Ricoeur (1989) sobre a não-separação entre pensamento e linguagem na produção e interpretação de metáforas (cf. também Moura, 2005).

Para mostrar que as metáforas são regidas por padrões lingüísticos de interpretação, Moura (2007) apresenta uma metodologia de análise de verbos de mudança de estado usados metaforicamente: explodir, arquivar e congelar. $\mathrm{O}$ autor explica passo a passo a metodologia de análise de metáforas utilizada: definição da categoria semântica (nominal ou verbal), definição de uma lista com itens lexicais pertencentes à categoria escolhida, pesquisa na web de ocorrências dessas metáforas, e análise propriamente dita que engloba a identificação de paráfrases de cada metáfora, sua respectiva classe semântica, relação sintagmática (englobando o tópico e o veículo) e a dimensão relevante do tópico. $\mathrm{O}$ autor conclui que há regularidades de combinações categoriais (relações sintagmáticas e paradigmáticas) para guiar uma interpretação metafórica, ou seja, "[..] ao formar sentenças, combinamos não exatamente palavras, mas categorias de palavras, que obedecem a restrições e hierarquias.” (MOURA, 2007, p. 449). 
Moura (2008) faz uma reflexão em torno da autonomia da metáfora em relação à frase e conclui que não é possível dicotomizar de maneira tão extremista a relação entre a palavra e a sentença, pois "[...] a palavra só funciona quando ocorre uma predicação [...]” (MOURA, 2008, p. 7). A teoria estruturalista de Ullmann (1964) apresenta a origem da metáfora no sistema lexical, e Moura (2008) se contrapõe a essa idéia, argumentando que a metáfora nasce da interação entre tópico e veículo e não apenas da superposição de um novo significado a um significado antigo do signo.

Em seu trabalho, Ullmann (1964) enfatiza a importância dos estudos semânticos para a Lingüística e descreve a metáfora como uma mudança de significado, com estrutura binária: "[...] há sempre dois termos presentes: a coisa de que falamos e aquilo com que a estamos a comparar” (1964, p. 442). Também divide a metáfora em quatro tipos: antropomórficas, sinestésicas, animais e metáforas que vão do concreto ao abstrato. Para Ullmann (1964), a metáfora é tão importante que é inconcebível existir qualquer língua desprovida de metáforas. Além disso, o autor destaca a importância do contexto e a teoria dos campos semânticos para o progresso nos estudos da semântica.

A teoria dos campos semânticos é defendida por Kittay (1989), e a autora ressalta também a importância do contexto na interpretação metafórica. Kittay (1989, p. 39) afirma: "Metaphor is a primary way in which we accommodate and assimilate information and experience to our conceptual organization of the world”.. Kittay (1989) parte da teoria interacionista de Black (1993) para formular sua teoria de análise de metáforas.

A maioria dos autores afirma que a metáfora possui uma estrutura binária, i.e., é estruturada pela interação entre o tópico e o veículo. Alguns teóricos utilizam outras palavras para expressar esse mesmo conceito, como por exemplo: alvo e fonte, teor e veículo, entre outros. Utilizaremos aqui a nomenclatura adotada em Moura (2005) para designar a idéia que cada um dos elementos representa. "Os dois elementos constitutivos da metáfora são o tópico e o veículo. O tópico é a entidade da qual se fala na metáfora, e o veículo é a expressão lingüística que predica sobre o tópico.” (MOURA, 2005).

A pesquisa tem por objetivo coletar metáforas ontológicas com verbos de atitude proposicional. Dentro dessa classe de metáforas ontológicas, o foco será nas metáforas de personificação, isto é, quando "[...] objetos físicos são concebidos como pessoas [...]” (LAKOFF; JOHNSON, 2002, p. 87). As metáforas de personificação estudadas serão aquelas que atribuem pensamento a máquinas, como por exemplo; “o computador pensa” (tópico: computador, veículo: pensa). Cada uma das metáforas coletadas será analisada, e os resultados comprovarão ou não a hipótese levantada, que vem a ser a seguinte: as categorias semânticas e suas respectivas combinações são acionadas na interpretação de uma metáfora, portanto há uma regularidade para a interpretação metafórica, classes específicas de verbos guiam uma interpretação específica dos enunciados metafóricos.

\section{METÁFORAS DE PERSONIFICAÇÃO E INTELIGÊNCIA ARTIFICIAL}

Antes de entrarmos na análise das metáforas, é necessário perceber que há uma relação muito estreita entre o uso das metáforas de personificação e a Inteligência Artificial. 
Isso ocorre porque existe um grande embate filosófico entre os defensores da AI (Artificial Inteligence) e os teóricos que afirmam que as máquinas não são inteligentes, ou seja, elas não têm a capacidade de pensar como os seres humanos, mas possuem apenas a aptidão de manipular símbolos. Não iremos nos aprofundar na discussão sobre Inteligência Artificial, mas apenas mostrar a relação que esse tema tem com o uso metafórico. Afinal, aqueles que acreditam realmente que as máquinas podem ser inteligentes, utilizam verbos de conteúdo proposicional no sentido literal, e aqueles que excluem a possibilidade de as máquinas possuírem a mesma habilidade de um ser humano, utilizam tais verbos no seu estrito sentido metafórico.

Essa discussão filosófica em torno da inteligência das máquinas, principalmente do computador, pode ser um dos fatores pelos quais as metáforas nesse sentido passaram a ser cada vez mais comuns no cotidiano das pessoas. Muitas vezes essas metáforas são usadas como um meio de ilustrar melhor o que se quer dizer. Se uma pessoa quer falar, por exemplo, que o computador processa informações complexas em pouco tempo, ela poderá dizer: "Esse computador pensa rápido." Da mesma maneira, se uma pessoa quer dizer que seu computador (ou qualquer outra máquina) apresenta um funcionamento irregular, a pessoa poderá falar: "Meu computador enlouqueceu." Podemos perceber que as duas metáforas apresentadas são parcialmente parafraseáveis, ou seja, um falante prefere dizer metaforicamente ao invés de se expressar literalmente, pois a metáfora consegue se aproximar muito mais daquilo que ele quer dizer.

Essas metáforas de personificação, entretanto, são polêmicas, porque os defensores da Inteligência Artificial afirmam que uma máquina pode pensar como um ser humano e, nesse caso, a proposição "Meu computador pensa.", estaria sendo tomada em seu sentido literal. Um dos teóricos da Inteligência Artificial, Allan Turing (1950), propõe um teste para provar que os computadores pensam como seres humanos. "Turing supõe não haver nenhuma diferença e, assim, acredita que um computador que passe pelo seu teste, que seja confundido com um ser humano, realmente é uma máquina pensante.” (PORTO, 2006, p. 14).

Em contraposição a essa teoria, Searle (1980) propõe um experimento para refutar o teste de Turing. "O experimento ficou conhecido como o 'argumento da sala chinesa' e talvez seja o experimento mental mais famoso em toda a discussão sobre a possibilidade da inteligência Artificial”. (PORTO, 2006, p. 16). O experimento de Searle consiste no seguinte: hipoteticamente, Searle entra numa sala e, mesmo desconhecendo o idioma chinês, recebe dois papéis escritos em chinês e uma folha escrita em inglês, explicando que, sempre que na primeira linha da primeira folha ocorresse certo grupo de símbolos e na primeira linha da segunda folha, outro grupo de símbolos, ele deveria escrever um grupo diferente de símbolos num terceiro papel, o qual deveria estar em chinês e ser enviado por uma janela para alguém do lado de fora da sala. As folhas em chinês eram perguntas, e a folha que Searle escreveu, mesmo sem saber chinês, resultou numa perfeita resposta às perguntas; ou seja, Searle está apenas manipulando símbolos; ele não sabe o conteúdo daquilo que escreve, apenas a forma. É assim que o filósofo explica a suposta Inteligência Artificial das máquinas. Para Searle (1980), o computador tem apenas habilidades sintáticas, enquanto o ser humano possui habilidades sintáticas e semânticas. Além disso, o autor introduz o conceito de "intencionalidade”, afirmando que a capacidade semântica é necessariamente intencional. 
Essa discussão obviamente não termina com o argumento da sala chinesa. Os defensores da Inteligência Artificial apresentaram suas réplicas e ainda há muito que refletir sobre esse aspecto. O que nos interessa, entretanto, é mostrar que as metáforas de personificação são cada vez mais comuns na linguagem científica e no cotidiano das pessoas. O uso constante de tais metáforas, porém, pode mudar de sentido metafórico para literal, conforme o ponto de vista de quem fala.

Abordamos esse assunto porque, conforme os dados coletados, percebemos que, algumas vezes, aparecem frases em forma de perguntas, como por exemplo: "Será que um computador pode pensar?”. E a interrogação, nesse caso, impede-nos de interpretar se o uso é metafórico ou literal, pois a dúvida traz essa dupla possibilidade de sentido. As eventuais dúvidas em relação ao uso da metáfora podem ser explicadas pela discussão filosófica acerca da Inteligência Artificial.

\section{MATERIAIS E MÉTODOS}

O método utilizado para a pesquisa é dividido em seis partes de acordo com o modelo de Moura (2007):

1) Definir uma categoria semântica (nominal ou verbal) que ocorra na posição de veículo das metáforas a serem investigadas.

2) Definir uma lista de itens lexicais pertencentes à categoria semântica escolhida (construção da relação paradigmática).

3) Pesquisar na web ocorrências de metáforas com esses itens lexicais na posição de veículo.

4) Identificar, na análise de dados, classes de interpretação (conjuntos de paráfrases) que possam ser inferidas a partir dos dados, para cada item lexical analisado.

5) Identificar possíveis correlações entre classes de interpretação e relações sintagmáticas (construção das relações sintagmáticas).

6) Comparar as relações sintagmáticas dos diferentes itens lexicais, obtidas no quinto passo, e identificar padrões de interpretação válidos para os diferentes itens. Se padrões de interpretação forem encontrados, postular um tipo de metáfora.

(MOURA, 2007)

Primeiramente é definida a categoria semântica dos veículos usados nas metáforas; após essa definição, uma lista de itens lexicais específicos é escolhida. Disponibilizada a lista, inicia-se a coleta de metáforas na web, incluindo os contextos frasais sempre que possível e visando descrever minuciosamente cada metáfora em uma análise posterior. O primeiro passo na análise das metáforas é identificar as paráfrases possíveis para cada metáfora, e a segunda etapa consiste em evidenciar as correlações entre classes de interpretação e relações sintagmáticas, identificando a paráfrase, os tópicos, a classe semântica, a dimensão relevante do tópico e a relação sintagmática (tópico e veículo). Feita a análise de dados, as relações sintagmáticas dos diferentes itens lexicais serão comparadas com o objetivo de identificar padrões de interpretação, se estes forem encontrados, a hipótese será comprovada ou não. 


\section{RESULTADOS E DISCUSSÃO}

A categoria gramatical escolhida foi a verbal, mais especificamente, os verbos relacionados a atitudes proposicionais. Os itens lexicais estipulados foram: pensar, raciocinar, surtar, pirar, enlouquecer, inventar, acreditar, criar, decidir, saber, acreditar, entender, aceitar, querer, achar; os quais foram utilizados como veículos das metáforas. Com a lista em mãos, foi feita uma coleta na web de exatamente 51 metáforas de personificação referentes aos seguintes tópicos: computador, celular, aparelho, televisão, microondas, avião, carro, piloto automático, termostato, aparelho e máquinas.

Os verbos (veículos) escolhidos foram sublinhados, e cada um dos dados foi separado conforme os tópicos. Foram encontrados dezessete (17) exemplos com o verbo pensar, um (1) com o verbo raciocinar, seis (6) com enlouquecer, cinco (5) com surtar, dois (2) com pirar, sete (7) com decidir, um (1) com inventar, dois (2) com saber, três (3) com entender, um (1) com acreditar, um (1) com aceitar, um (1) com criar, dois (2) com querer e dois (2) exemplos com o verbo achar.

\section{COMPUTADOR}

(1) O computador já "pensou" numa coisa (animal), mas não a revela. 3. O jogo é acompanhado por um sistema de pontuação.

http://www.mocho.pt/search/local.php?info=local/software/multidisciplinar/jcoisas1/ma nual.html

(2) O meu computador pensou que a garantia tinha acabado e decidiu deixar de funcionar.!

http://paperdragon.wordpress.com/2007/08/31/unholy-quest-for-arranjo-do-

computador/

(3) O meu computador pensou que a garantia tinha acabado e decidiu deixar de funcionar.!

http://paperdragon.wordpress.com/2007/08/31/unholy-quest-for-arranjo-docomputador/

(4) No jogo, o computador "pensa" numa de várias coisas que são mostradas ao jogador (por meio de imagens, palavras, sons e filmes). O jogador tem de advinhar qual é a coisa em que o computador "pensou", colocando o menor número possível de questões (às quais o computador responde com sim ou não).

http://www.instituto-camoes.pt/cvc/cdrom/44/jogocoisas.html

(5) O que vamos abordar aqui pode chocar o leitor, mas é verdade: o computador não pensa em português. Ele entende apenas 0 e 1. Isso mesmo, você entendeu certo: zero e um.

http://www.sociedadedigital.com.br/artigo.php?artigo=44\&item=5

(6) O computador entende apenas o 0 e o 1 que em binário (porque são apenas dois algarismos) representam desligado e ligado, respectivamente.

http://www.sociedadedigital.com.br/artigo.php?artigo=44\&item=5 
(7) O cérebro do computador é o seu processador, que lhe dá a capacidade de pensar. Quanto mais rápido o processador, mais rápido o computador pensa. Em nossa vida corrida, precisamos de um computador que possa fazer coisas para nós o mais rápido possível.

http://www.seed.slb.com/pt/scictr/watch/computer/index.htm

(8) O Computador acredita que os comunistas infiltraram seus agentes entre a população. São eles os mutantes, falhas secretas imperfeitas (e poderosas) demais para existir; e as sociedades secretas, entidades clandestinas não autorizadas que pregam a mais loucas filosofias de vida - desde o ódio contra todas as máquinas até o saudosismo por coisas importantes do passado (as orelhas do Mickey, por exemplo). Em sua infinita sabedoria, o computador criou uma unidade especial conhecida como Agentes Atiradores

http://www.rederpg.com.br/portal/modules/news/article.php?storyid=348

(9) O Computador acredita que os comunistas infiltraram seus agentes entre a população. São eles os mutantes, falhas secretas imperfeitas (e poderosas) demais para existir; e as sociedades secretas, entidades clandestinas não autorizadas que pregam a mais loucas filosofias de vida - desde o ódio contra todas as máquinas até o saudosismo por coisas importantes do passado (as orelhas do Mickey, por exemplo). Em sua infinita sabedoria, o computador_criou uma unidade especial conhecida como Agentes Atiradores

http://www.rederpg.com.br/portal/modules/news/article.php?storyid=348

(10) Não sei mais o que fazer... meu computador enlouqueceu após eu instalar o Service Pack 2 através do Windows Update.

http://forum.clubedohardware.com.br/archive/meu-computador-enlouqueceu/147905

(11) É só falar que o computador surtou com tanto trabalho. http://forum.cifraclub.terra.com.br/forum/11/182676/p1

(12) Será que um computador pode raciocinar como a gente? http://www.canalkids.com.br/central/arquivo/tec_cyc.htm

(13) Meu computador pirou??? Antigamente não havia problema, hoje o pc não "aceita" alguns jogos. O que está ocorrendo?

http://gamesbrasil.uol.com.br/forum/showthread.php?t=18316

(14) Antigamente não havia problema, hoje o pc não "aceita" alguns jogos. O que está ocorrendo?

http://gamesbrasil.uol.com.br/forum/showthread.php?t=18316

(15) Aquilo que o computador "sabe" não sabe apenas procura partidas anteriormente jogadas que contenham a posiçao actual do seu jogo (...)

http://pokerpt.com/forum/homem-vs-maquina-vt7462.html 


\section{CELULAR}

(16) Já era meio-dia! Por algum motivo que não consigo entender, o meu celular enlouqueceu no estado de São Paulo. Como a Oi não tem cobertura local, aqui ele se transformou em Oi TIM.

http://grimorium2.zip.net/arch2006-02-01_2006-02-28.html

(17) É que o celular surtou e não queria baixar as fotos...hum horror!!

http://www.flogao.com/carlahupsel/foto/105/118834336

(18) meu celular surtou e parou de funcionar. precisei dar reboot.

http://tumblr.markun.com.br/page/123

(19) Meu celular decidiu me dar um susto,...por cerca de 20 minutos ele simplesmente se negou a ligar.

http://ditospelomaldito.blogspot.com/2008/06/tlemvel-maldito.html

(20) Hoje de manhã, meu celular decidiu que eu iria dormir mais. Atrasou UMA hora. Uma hora inteira.

http://accid.blogspot.com/2006/09/funniest-picture-of-world.html

\section{TELEVISÃO}

(21) Tive que fazer isso porque o filme que o Erro gravou pra mim não ta rodando no pc, e a minha televisão surtou de vez. Num domingo. Ótimo, sem Faustão nem Fantástico por hoje.

http://battologizzze.livejournal.com/

(22) Chove lá fora e eu aqui no cantinho do meu quarto, a ouvir música já que a minha televisão decidiu parar de funcionar.

http://zig.blogs.sapo.pt/2005/10/

(23) Minha televisão pirou. O texto falado aparecia escrito, numa óbvia função para deficientes. Mexi, mexi e o aparelho ficou mudo!

http://www.quemtemsedevenha.com.br/coisas_que_eu_nao_sei.htm

\section{MICROONDAS}

(24) Você já teve a sensibilidade de imaginar o que seu forno de microondas pensou no dia em que ele saiu da caixa e estacionou na cozinha?

http://www.eduardozugaib.com.br/cotidiano-c3.htm

(25) Recentemente, além de apitar com insistência quando acaba o servço, meu microondas decidiu enviar uma mensagem e lá, no visor, pode-se ler agora a palavra 'fim'.

http://www.anjosdeprata.com.br/aatemas/2008/171/171docarmelo.htm 


\section{APARELHO}

(26) Depois de uma fase maravilhosa de flores e declarações de amor com meu DR175B, veio o primeiro desentendimento: O aparelho enlouqueceu. Grava, para de gravar, exibe a gravação sozinho (...)

http://www.htforum.com/vb/showthread.php?p=701902

(27) A porra do aparelho pensou, pensou, pensou e nada. Medir o meu sangue que é bom...népia. Dava um valor muito baixo.

http://avidadegi.blogspot.com/

(28) Basicamente, o filme tinha uma relação de aspecto de 1,77:1 enquanto que o aparelho achou que ele era um filme de 1,85:1, como você pode ver pela adição de faixas pretas na parte superior e inferior da tela.

http://www.clubedohardware.com.br/artigos/1451/3

\section{MÁQUINA}

(29) Proponho que consideremos a questão: "Podem as máquinas pensar?". Deveríamos começar com as definições do significado dos termos: "máquina" e "pensar".

http://www.educ.fc.ul.pt/docentes/opombo/seminario/turing/index.htm

(30) "A máquina enlouqueceu", exclamaram mais uma vez as três, incrédulas. http://paixaodaleitura.blogspot.com/2007/03/contos-estelares-vii.html

(31) Agora vais fazer pesquisa onde uma maquina inventou um lance num heads up vs human 9 . o Kasparov "inventou" um, no celebre empate após as vitorias consecutivas do kaspas e não foi por isso que perdeu.

http://pokerpt.com/forum/homem-vs-maquina-vt7462.html

(32) É, a minha máquina surtou de vez. Vezenquando liga, vezenquando não. http://e.entao.com.br/categoria/bugs

(33) "o teste de Turing estabelece o seguinte critério para decidirmos se uma máquina pensa: se o comportamento de uma máquina for indistinguível daquele exibido por um ser humano, não há razão para não atribuir a essa máquina a capacidade de pensar."

http://www.patio.com.br/labirinto/Mentes\%20e\%20m\%E1quinas\%20-

\%20Fernandes\%20Teixeira.htm

(34) uma das formas de se lidar com a 424 dos adversarios ao final das partidas e pensar da mesma forma que a maquina pensa quando vc manda todos para o ataque....

http://forum.fmanager.com.br/lofiversion/index.php/t35543.html

\section{PILOTO AUTOMÁTICO}

(35) piloto automatico queria pousar, e bugou, enquanto o piloto tentava puxar o aviao $\mathrm{p}$ cima....

http://forum.hardmob.com.br/showthread.php?t=278814 
(36) Em vez de um jogar colectivo, a estrutura move-se por impulsos individuais. É a vertigem do piloto automático que não pensa. Ataca por picos e a seguir faz uma transição defensiva desequilibrada.

http://travessadamalingua.blogspot.com/2008/02/o-piloto-automtico.html

(37) O piloto automático achou que o piloto queria virar para a esquerda e tentou ajudar. http://homepages.dcc.ufmg.br/ scampos/cursos/rt/aulas/rt01.html

(38) como o piloto automatico sabe se nao quero voltar pela radial para o vor?

http://www.aerovirtual.org/forum/index.php?showtopic=53830

\section{TERMOSTATO}

(39) John McCarthy: "O meu termostato tem três crenças - está demasiado quente aqui, está demasiado frio aqui e está bem aqui” (Searle, 1997a, p. 38) - se, ter crenças é pensar; então, o termostato pensa?

http://209.85.215.104/search?q=cache:cAJR_KeiUg8J:www.seer.ufrgs.br/index.php/Inf EducTeoriaPratica/article/view/2304/1005+\%22termostato+pensa\%22\&hl=pt-

BR\&ct $=$ clnk\&cd $=2 \& g l=b r \& l r=l a n g \_p t$

(40) As casas aqui sãos totalmente climatizadas e o termostato pensa pra gente: tá frio ele esquenta, tá calor ele esfria. E o ambiente fica gostoso.

http://perplexoinside.blogspot.com/2006/03/informao-relevante.html

(41) Apesar de a temperatura no apartamento já ter sido aumentada, o termostato pensa que está baixa por causa do frio da parede externa.

http://books.google.com.br/books?id=PH6ljbOq9mgC\&pg=PA107\&lpg=PA107\&dq=

$\% 22$ termostato+pensa $\% 22 \&$ source $=$ web\&ots $=$ pT-

oCUClSb\&sig=eiazLf8z16XgHMxU27RS6AiaWwk\&hl=pt-

$\underline{\text { BR\&sa }=X \& o i=\text { book_result\&resnum }=4 \& \mathrm{ct}=\text { result }}$

(42) Se admitirmos o ato de pensar restrito ao nívelsintático-funcional, podemos afirmar que —um termostato pensa“", mantendo as devidas proporções.

http://209.85.215.104/search?q=cache:entmUD4fA2AJ:cognitio.incubadora.fapesp.br/p ortal/atividades/cursos/posgrad/vida_artificial/2008/exercicios/pensamento\%2520artific ial/Flavio_E3.pdf $+\% 22$ termostato+pensa\%22\&hl=pt-

$\underline{\mathrm{BR} \& \mathrm{ct}=\mathrm{clnk} \& \mathrm{~cd}=3 \& \mathrm{gl}=\mathrm{br} \& \mathrm{lr}=\text { lang } \_\mathrm{pt}}$

\section{CARRO}

(43) simplesmete o carro ENLOUQUECEU não funcionava os vidros elétricos, o computador de bordo ficava indicando super-aquecimento no radiador e mandava desligar o carro (...)

http://www.puntoclube.com/forum/viewtopic.php?t=780\&highlight=\&sid=710a645788 e04ed24272b35971fe5b62

(44) À saída do emprego, na avenida mais movimentada da cidade e em hora de ponta, o estúpido do meu carro enlouqueceu e pôs-se a acelerar sozinho sem pedir nada a ninguém. 
http://farinhamparo.blogspot.com/2008/03/vida-bela-mas-umas-vezes-mais-bela$\underline{\text { do.html }}$

(45) Os CB fazem o cálculo sp para gasolina, pois o carro pensa que está a gasolina... http://www.forum.autogas.pt/forum/viewtopic.php?f=14\&t=1094\&st=0\&sk=t\&sd=a\&st $\underline{\operatorname{art}=60}$

(46) Isto tudo porque o carro decidiu bloquear as rodas quando eu carreguei ao de leve no pedal de travão...

http://www.autoportal.pt/lermsg.asp?MsgO=44439\&IdMsg=44447\&IdForum=1

(47) O carro quis voar. Eu dirigi o carro muito delicadamente, entretanto, o mesmo dia eu comprei o carro, e deslizou os rolamentos e quebrou-os para baixo.

http://www.trustmymechanic.com/pt/auto-repair/30/my-neighbors-1970-dodge-charger$\underline{440 \text {-six-pack.html }}$

\section{AVIÃO}

(48) É verdade, mas fazendo isso fica um conflito, pois o avião pensa que vai chegar em SJTC, o controle vai guiar o avião pra SJTC sendo que não existe SJTC.

http://www.aerovirtual.org/forum/lofiversion/index.php/t97918.html

(49) Infelizmente, o avião decidiu tremer além dos limites estabelecidos pelos meus nervos, mas ainda tenho espaço para sugerir a pais e mães trogloditas que pensem antes de bater nos filhos.

http://www.olobo.net/index.php?pg=artigos\&id=690

(50) O piloto tinha inclinado o avião só que o computador não deixou mais, pois o ângulo poderia estar próximo do limite, então o cmte acelerou um motor e diminuio o outro para ajudar o avião a virar, porem o avião entendeu que estava perdendo um dos motores, fazendo com que o avião aplicasse pedal movendo o avião justo para cima do morro.

http://www.aerovirtual.org/forum/index.php?s=b50b78840e81438f5d9cc6524c5e56bb\& showtopic $=92833 \&$ st $=30 \& p=800388 \& \#$ entry 800388

(51) O avião entendeu que a intenção do comandante era acelerar ao invés de frear. Como a pista era ampla e tinha longa área de escape, a aeronave seguiu mais alguns metros e parou em uma vala.

http://clipping.planejamento.gov.br/Noticias.asp?NOTCod=372654

Após a coleta de dados, conforme o quarto passo do método proposto por Moura (2007), foram identificadas duas paráfrases inferidas a partir das metáforas coletadas. Nessa primeira fase da análise, identificamos as paráfrases: a) funcionamento regular e irregular e b) processar informação. Juntamente com as paráfrases, colocamos seus respectivos exemplos e os verbos utilizados como veículos entre os exemplos. Alguns exemplos não se encaixaram em nenhuma das paráfrases identificadas, e não constituíam nenhuma outra paráfrase, pois não se trata, na verdade, de metáforas, já que são usos ficcionais. Voltaremos a esse ponto na seção ulterior, onde tentaremos explicar o porquê de o uso ficcional não constituir metáfora. 
Paráfrase (a): funcionamento regular e irregular.

Exemplos: (3), (10), (11), (13), (14), (16), (17), (18), (19), (20), (21), (22), (23), (25), (26), (27), (28), (30), (32), (35), (36)*, (37)*, (40)*, (41)*, (42), (43), (44), (45)*, (46), (47), (48)*, (49), (50)*, (51)*.

Verbos: decidir, enlouquecer, pirar, aceitar, surtar, achar, querer.

Paráfrase (b): processar informação.

Exemplos: (1), (2), (4), (5), (6), (7), (9), (15), (27), (28), (29), (31), (33), (34), (36)*, $(37)^{*},(38),(40) *,(41)^{*},(45)^{*},(48) *,(50) *,(51)^{*}$.

Verbos: saber, pensar, entender, achar, raciocinar.

Passo 5: Identificar possíveis correlações entre as classes de interpretação e relações sintagmáticas (construção de relações sintagmáticas). Em cada paráfrase, acrescentamos os tópicos das metáforas que possuem tal interpretação. A classe semântica permanece igual para todas as paráfrases, pois já havia sido definido que os tópicos pertenceriam à classe semântica das máquinas. Cada um dos tópicos são hipônimos de máquinas, porque são dessa classe semântica, no entanto são mais específicos.

Paráfrase (a): funcionamento regular e irregular.

Exemplos: (3), (10), (11), (13), (14), (16), (17), (18), (19), (20), (21), (22), (23), (25), (26), (27), (28), (30), (32), (36)*, (35), (37)*, (40)* (41)*, (43), (44), (45)*, (46), (47), (48)*, (49), (50)*, (51)*.

Verbos (veículos): decidir, enlouquecer, pirar, aceitar, surtar, achar, querer.

Tópicos: computador, celular, televisão, microondas, carro, aparelho, máquina, piloto automático, carro, avião.

Classe semântica (Hiperonímia): máquinas

Dimensão relevante do tópico: funcionamento

Relação sintagmática (a): Tópico (máquinas), Veículos (decidir, enlouquecer, pirar, aceitar, surtar, achar, querer).

Paráfrase (b): processar informação.

Exemplos: (1), (2), (4), (5), (6), (7), (9), (15), (27), (28), (29), (31), (33), (34), (36)*, (37)*, (38), (40)*, (41)*, (45)*, (48)*, (50)*, (51)*.

Verbos (veículos): saber, pensar, entender, achar, saber

Tópicos: computador, aparelho, máquina, piloto automático, termostato, avião.

Classe semântica (Hiperonímia): máquinas

Dimensão relevante do tópico: informação

Relação sintagmática (b): Tópico (máquinas), Veículos (saber, pensar, entender, achar, raciocinar)

Conforme a análise feita,é possível perceber que há uma regularidade na interpretação das metáforas. As paráfrases identificadas, contudo, não são absolutas, pois cada metáfora possui sua peculiaridade, visto que as metáforas são insubstituíveis. O que tentamos fazer foi encontrar uma interpretação que se aproximasse ao máximo do sentido que a metáfora apresenta.

Nas metáforas (1) e (4) foi identificada a mesma paráfrase; processar informação, e o tópico de ambas é o computador. É interessante notar que o veículo (o verbo pensar) está entre aspas, o que significa que está sendo usado metaforicamente. O uso da aspas é 
uma maneira comum para mostrar que o uso é não-literal. Até mesmo na linguagem oral, os indivíduos utilizam as aspas, mostrando com os dedos, para indicar que o sentido da palavra não é literal. O uso desse recurso aparece também nas metáforas (14) e (15) cujos veículos são aceitar e saber, ainda se referindo ao mesmo tópico das metáforas citadas anteriormente.

Com base nos dados coletados, o uso das aspas apareceu nas metáforas cujo tópico é computador e, excepcionalmente, na metáfora (31) cujo tópico é máquina e o veículo é inventar. Analisando o contexto, no entanto, é possível perceber que a máquina referida no texto é um computador. A utilização de máquina ao invés de computador acontece porque este é hipônimo de máquina, assim como os outros tópicos (termostato, carro, avião, celular e outros) são hipônimos do hiperônimo máquina. Dessa forma, podemos concluir que apenas quando se trata do tópico computador, aparece o uso das aspas. É uma característica relevante, pois, quando ocorre um exemplo utilizando o carro ou um avião como tópico e o verbo pensar como veículo, as aspas não aparecem. Isso acontece porque é muito óbvio que um carro ou avião não pensam, por isso a interpretação metafórica vem logo à tona. Mas o veículo pensar relacionado ao computador pode ser utilizado no sentido metafórico ou não. Os defensores da Inteligência Artificial, por exemplo, quando dizem que um computador pensa, utilizam o verbo em sentido literal. Dessa forma, aqueles que não acreditam que haja inteligência nas máquinas, precisam de um diferencial para ilustrar que estão usando o sentido metafórico. Nossa hipótese é de que, quando o tópico é o computador e o veículo é um verbo de conteúdo proposicional, há uma ambigüidade de sentidos; o literal e o metafórico, e as aspas servem, nesse caso, para tirar a ambigüidade e mostrar que se trata de uma metáfora.

Outra característica, que tem influência da mesma questão, é o uso da interrogação. Alguns exemplos coletados são perguntas, e muitos deles envolvem diretamente a questão da AI (Artificial Inteligence). O item (12), por exemplo, exprime uma dúvida sobre a questão, por isso, em uma leitura sem contexto, não podemos identificar se o sentido é metafórico ou não, por não se tratar de uma afirmação. Conforme o contexto do exemplo coletado, é possível perceber que o "raciocinar”, referido na pergunta, foi utilizado no sentido literal; é um texto que noticia às crianças que uma equipe está empenhada em ensinar o computador a raciocinar. O próprio texto menciona que parece coisa de filme, mas não é uma brincadeira, isto é; é semelhante à ficção científica, mas o sentido do verbo é literal mesmo.

O exemplo (39) também expressa uma dúvida sobre a capacidade de pensar do termostato. O fragmento foi retirado do artigo de Porto (2006) sobre a discussão filosófica acerca da Inteligência Artificial. Segundo o contexto do exemplo (39), a suposta metáfora é baseada na frase de John McCarthy sobre as "crenças" do termostato, mas o próprio uso do termo crenças para se referir à capacidade de um termostato já é uma metáfora. É bastante claro, no entanto, que John McCarthy, ao afirmar que um termostato tem crenças, utiliza o sentido literal em sua sentença. $\mathrm{O}$ texto propõe que ter crenças pressupõe pensamento e, portanto, as crenças do termostato poderiam ser frutos do pensamento dessa máquina. O contexto nos permite entender que o verbo pensar seria utilizado em sentido literal se a sentença fosse uma afirmação, pois o resultado disso seria o silogismo: "Se ter crenças é pensar, e o termostato tem crenças, então o termostato pensa.”, contudo a interrogação por si só nos impede de interpretar se 
tal exemplo é uma metáfora ou não, já que traz a dúvida acerca da questão da existência da Inteligência Artificial.

O exemplo (42), apesar de não trazer a interrogação, também traz consigo a dúvida na interpretação do uso metafórico ou não. O elemento que traz a dúvida é o "se", pois o exemplo diz que: "se admitirmos o ato de pensar restrito ao nível sintático-funcional", podemos afirmar que um termostato pensa (em seu sentido literal). Mas se pensar é mais que isso, ou seja, engloba capacidades semânticas (como já discutíamos na seção sobre AI), o termostato não possui essa capacidade do pensamento. Ao nos aprofundarmos na análise do item (42), percebemos que é mais uma “falsa metáfora", pois aparentemente parece ter sentido figurado, mas, quando percebemos o contexto e relacionamos o fragmento à discussão da Inteligência Artificial, notamos que o verbo pensar é utilizado em seu sentido literal, pois os defensores da AI acreditam piamente que uma máquina pode pensar.

Três dentre os exemplos - (12), (39) e (42) - não foram interpretados como exemplos de metáfora, graças à questão da Inteligência Artificial que faz com que o sentido dos verbos possa ser literal, por isso não os classificamos em nenhuma das paráfrases.

Alguns exemplos englobaram as duas paráfrases identificadas e não apenas uma delas. Essas metáforas estão nos seguintes exemplos: (27), (28), (36), (40), (48), (50) e (51). Os exemplos referidos estão marcados pelo asterisco e aparecem na identificação de exemplos das duas paráfrases. O primeiro deles (27) utiliza o tópico aparelho e o veículo pensar, e a interpretação é de que o aparelho processou a informação, mas não funcionou. O exemplo (28) apresenta o mesmo tópico e do veículo achar e, pelo contexto, o aparelho processou a informação de maneira equivocada, e isso resultou num funcionamento irregular.

O exemplo (36) traz o verbo pensar e o tópico piloto automático. Segundo o contexto, a máquina não processa a informação que deveria processar e acaba se "desequilibrando". O exemplo (40) apresenta o mesmo veículo, no entanto o tópico é termostato, e o termostato processa a informação conforme a temperatura do lugar para funcionar de uma maneira que deixe a temperatura agradável.

O exemplo (48) parte da interação do tópico avião com o veículo pensar; a máquina processa uma informação errada que resulta num funcionamento irregular. Os exemplos (50) e (51) apresentam o mesmo tópico do exemplo citado anteriormente e o veículo entender. Em ambos os exemplos, o avião processa a informação equivocada e acaba funcionando de maneira errada.

A interação entre o tópico, formado por máquinas, e o veículo, constituído por verbos de atitude proposicional, das metáforas analisadas nos levou a apenas duas paráfrases: funcionamento regular ou irregular e processamento de informação. Essas paráfrases, no entanto, possuem diferenças entre si. A primeira delas acontece nas metáforas constituídas pelos verbos decidir, enlouquecer, pirar, aceitar, surtar, achar, querer; verbos que indicam atitudes mentais e algumas vezes mudança de estado. As metáforas constituídas pelos verbos saber, pensar, entender, raciocinar, achar (o único verbo presente nas duas classes), isto é, verbos ligados à descrição do processo do pensamento, tiveram a paráfrase do processamento de informação. 
Com isso, refletimos se a regularidade não acontece também nesse aspecto, pois, dentro da categoria verbos de atitude proposicional, existem duas subcategorias e estas são essenciais para que haja duas interpretações das metáforas. Desse modo, é possível apresentar apenas uma paráfrase para cada subcategoria, e as metáforas se mostrariam mais regulares ainda em sua interpretação.

Não queremos dizer com isso que toda metáfora possui uma interpretação extremamente regular, pois o diferencial da metáfora é justamente o impacto que ela causa por trazer à tona algo fora do sentido literal, no entanto algumas metáforas são tão utilizadas que já se cristalizaram, e essa característica "impactante" da metáfora se perde por causa da freqüência com que é utilizada. Por outro lado, a abordagem que adotamos permite explicitar a produtividade de novas metáforas a partir de combinações conceituais pré-determinadas.

Os próprios exemplos que coletamos são típicos da fala de muitos indivíduos e algumas metáforas são de fato cristalizadas. Existem metáforas tão cristalizadas que os falantes, às vezes, não encontram sentido literal que consiga dar conta dessa metáfora. Tomemos com exemplo a metáfora (6): "O computador entende apenas o 0 e o 1 que em binário [...]”. Qual verbo nós poderíamos utilizar que substituísse o verbo entender? A própria paráfrase "processar informação" é apenas uma aproximação, não uma substituição completa do verbo utilizado em sentido metafórico.

Nesse sentido, percebemos que a metáfora é insubstituível, não há como fazer uma paráfrase exata de nenhuma metáfora. Como já dissemos, nosso objetivo era fazer uma paráfrase que se aproximasse ao máximo do sentido que a metáfora traz, mas não encontrar um sentido literal que substituísse por completo o sentido metafórico. É nesse aspecto que a metáfora, longe de ser uma simples figura de estilo, impõe um ganho cognitivo à estrutura da linguagem.

\section{FICCIONALIZAÇÃO}

Alguns exemplos à primeira vista pareciam ser metáforas, mas, ao observar o contexto de cada um deles, pudemos constatar que os sintagmas não eram metáforas, porque eram usos ficcionais, o que não é o mesmo que uso metafórico. Os exemplos (8) e (9) referem-se ao mesmo tópico (computador), e os veículos utilizados são acreditar e criar. Os itens são fictícios porque o texto trata de um jogo de RPG (Role Playing Game) e tais jogos estão no plano da ficção. Outra característica que nos leva a defender essa interpretação é que há traços de ironia nos exemplos, isso é bastante claro quando o texto se refere à “infinita sabedoria” do computador.

O item (24) mostra mais claramente o cunho da ficção existente no texto, pois menciona a "sensibilidade de imaginar" o pensamento do forno microondas. A imaginação não está no plano do real, está na ficção e, por isso, é bastante óbvio que se trata do uso ficcional do verbo pensar relacionado ao tópico microondas.

Ficcionalizar uma entidade é considerá-la dotada de propriedades que ela não tem no mundo real. A entidade é uma ficção, como os seres imaginários (Saci, duendes) ou personagens (Capitu, Hamlet). Se enunciarmos que o "microondas pensou", ficcionalizando o microondas, ou seja, criando um mundo no qual microondas tem 
sensações e consciência, o verbo pensar é literal nesse caso; o substantivo é que se refere a uma entidade imaginária, da mesma forma que em "Hamlet pensou”, Hamlet é ficcional, mas pensar não, é literal mesmo.

Dessa forma, percebemos que a metáfora está além da sentença. É necessário saber o contexto de algumas metáforas para constatar se implicam sentido metafórico ou literal. A leitura fechada de uma sentença pode provocar um equívoco de interpretação da metáfora, e o sentido literal pode ser tomado como metafórico. O uso de verbos de atitude proposicional na posição de veículos, em interação com os tópicos do hiperônimo máquina, traz consigo, às vezes, ambigüidade e apenas o contexto poderá resolver a dúvida numa interpretação como essa.

\section{CONCLUSÕES}

Com base na análise das metáforas coletadas, pudemos identificar duas paráfrases; uma ligada ao funcionamento regular e irregular das máquinas, e a outra vinculada ao processamento de informação. Além dessas paráfrases, foram encontrados exemplos que não constituíam metáfora, pois estavam em contextos ficcionais, e a metáfora traz uma ficcionalidade dentro do plano do real; quando sai desse plano, perde-se o sentido da metáfora. Outros exemplos eram marcados pela dúvida acerca da Inteligência Artificial e, por não serem afirmações, não é possível interpretar se são metáforas ou não, já que a dúvida é justamente esta: se as máquinas podem pensar (ou qualquer outro verbo de atitude proposicional) ou não.

A quantidade de exemplos coletados e a regularidade na interpretação deles nos permitem notar que parece haver "regularidades combinatórias e categoriais (relações sintagmáticas e paradigmáticas) que guiam a interpretação. Ao interpretar uma metáfora, acionamos categorias semânticas e combinações entre categorias semânticas, num processo composicional bastante similar ao que ocorre na construção de proposições ordinárias.” (MOURA, 2007). Essa regularidade na interpretação metafórica ocorreu porque o tópico de todos os exemplos pertence à classe das máquinas, e o veículo das metáforas pertence à classe dos verbos de atitude proposicional. Assim, toda metáfora em que ocorre interação do veículo formado por essa classe de verbos e do tópico composto por essa classe de palavras, haverá duas possibilidades de interpretação, que são precisamente as duas paráfrases encontradas, as quais decodificam parcialmente essas metáforas de personificação.

A ativação das categorias semânticas que acontece numa interpretação metafórica mostra a sistematicidade da metáfora; ou seja, se trocássemos o veículo de um dos exemplos coletados por qualquer outro verbo de atitude proposicional (que não fossem aqueles escolhidos para efetuar a pesquisa) a interpretação metafórica seria a mesma. Tomemos, por exemplo, o item (47): “O carro quis voar”. Se substituíssemos o veículo "quis” por "desejou”, a mesma paráfrase daria conta da interpretação dessa metáfora, porque ambos os verbos pertencem à mesma classe semântica. Da mesma maneira, se trocássemos o tópico “carro" por “caminhão”, a interpretação permaneceria, pois o novo tópico pertence também à classe do hiperônimo máquinas. Com isso, percebemos que há uma sistematicidade na interpretação das metáforas, pois é a escolha das classes de palavras que permite estruturar a interpretação metafórica. 
Para que tais interpretações em relação às metáforas de personificação ocorram, é necessário que haja uma semelhança entre as máquinas e os seres humanos, pois, se não houvesse, seria impossível formar uma metáfora que relacionasse características humanas a máquinas. "A metáfora é, então, um acontecimento semântico que se produz no ponto de intersecção entre vários campos semânticos.” (RICOEUR, 1989, p. 151). A interseção dos campos semânticos relacionados a pessoas e relacionados a máquinas é o que possibilita a metáfora. Esse ponto de interseção, no caso das metáforas coletadas na pesquisa, é constituído por duas características comuns aos humanos e às máquinas: manipulação de signos e funcionamento segundo certa ordem. Graças a essa interação de campos semânticos, é possível formular tais metáforas.

A metáfora possui também uma estrutura léxico-conceptual, pois se constitui no léxico; as palavras são necessárias para formar o enunciado metafórico, mas o pensamento é essencial para a composição da metáfora. "O pensamento não é determinado pela linguagem, mas depende da estrutura lingüística como código que traduz o pensável." (MOURA, 2008, p. 3). Sem a linguagem é impossível criar uma metáfora, é a escolha das classes semânticas e palavras apropriadas que originam a metáfora.

Com o resultado da pesquisa, conseguimos perceber que existe certa regularidade que rege a interpretação das metáforas, mais especificamente, a classe de verbos de conteúdo proposicional em interação com os tópicos do hiperônimo máquina guiam interpretações específicas dessas metáforas. Se não fosse assim, encontraríamos diversas paráfrases para cada exemplo coletado, mas, conforme pudemos averiguar, apenas duas paráfrases regiam a interpretação das metáforas de personificação relacionadas a máquinas.

\section{REFERÊNCIAS}

BLACK, M. More about metaphor. In: ORTONY, A. (Ed.). Metaphor and thought. Cambridge: Cambridge University Press, 1993. p. 19-41.

KITTAY, E. F. Metaphor: its cognitive force and linguistic structure. Oxford University Press, 1989.

LAKOFF, G.; JOHNSON, M. Metaphors we live by. Chicago: Chicago University Press. 1980. Edição brasileira: Metáforas da vida cotidiana. Tradução de M. S. Zanotto e V. Maluf. São Paulo: EDUC. 2002.

MOURA, H. Metáfora: das palavras aos conceitos. Letras de Hoje. Porto Alegre: Editora da PUSC-RS, 2005. p. 40-139, 20-45.

Relações paradigmáticas e sintagmáticas na interpretação de metáforas. Linguagem em (Dis)curso, 2007. p. 7-3, 417-452.

Desfazendo dicotomias em torno da metáfora: Revista de Estudos da Linguagem, 16:2, 2008.

PORTO, L. S. Uma investigação filosófica sobre a Inteligência Artificial. Informática na Educação: teoria \& prática. Porto Alegre, v.8, n.2, jan/jun 2006. p.11-26. 
RICOEUR, P. Metáfora viva. Porto: Res, 1989.

SEARLE, J. R. (1980) Minds, brains, and programs. Behavioral and Brain Sciences. Disponível em: http://www.bbsonline.org/documents/a/00/00/04/84/bbs0000048400/bbs.searle2.html. Acesso em: 21 de junho de 2008.

Metaphor. In: ORTONY, A. (Ed.) Metaphor and thought. Cambridge: Cambridge University Press, 1993. p. 83-111.

TURING, A.M. Computing machinery and intelligence. Mind, [1950] 59, 433-460. Acesso em: 30 de junho de 2008.

ULLMANN, S. Semântica - Uma introdução à ciência do significado. Lisboa: Fundação Calouste Gulbenkian, 1964. 